\title{
Internal Deficit-External Deficit Nexus in Africa: 1960-2012
}

\author{
Gérard Tchouassi ${ }^{1} \&$ Ngwen Ngangué ${ }^{1}$ \\ ${ }^{1}$ Department of Economics, Faculty of Economic and Management, University of Yaoundé II, Yaoundé, \\ Cameroon \\ Correspondence: Gérard Tchouassi, Department of Economics, Faculty of Economic and Management, \\ University of Yaoundé II, Po Box 1365 Yaoundé, Cameroon, Tel: 237-6-9992-0998. E-mail: \\ tchouassigerard@yahoo.fr
}

Received: February 23, 2015

Accepted: March 18, 2015

Online Published: May 25, 2015

doi:10.5539/ijef.v7n6p232

URL: http://dx.doi.org/10.5539/ijef.v7n6p232

\begin{abstract}
In this article, we have tested the causality correlation linking the internal deficit with the external deficit for a group of 15 African economies. Specifically, using causality analysis, we have tested the four possible causation linkages: (1) internal deficit causes external deficit, (2) there is bidirectional causality linking the two variables, (3) the two deficits are not causally related and (4) external deficits cause internal deficits. Using linear panel causality, this paper shows with heterogeneous Granger causality analysis that in five African countries, Côte d'Ivoire, Gambia, Morocco, Democratic Republic of Congo and Tunisia, external deficit Granger caused internal deficit. Two countries, Nigeria and Egypt, postulate causality from internal deficit to external deficit. While one country, South Africa, reveal a bidirectional causal link between internal deficit and external deficit. Monetary policies focused on the efficiency, as well as the exchange rate, will help to re-build, harmonize and control the budget policy in African countries.
\end{abstract}

Keywords: internal deficit, external deficit, public debt, twin deficits, ricardian equivalence, causality analysis

\section{Introduction}

Nexus internal deficit and external deficit is one of the most important macroeconomic troubles for all economic policy makers and advisors of the developed and developing world. Internal deficit problems appear because of excessive public expenditure over governmental revenue. External deficit problems occur because of excessive imports of goods and services over exportations. The relationship between internal and foreign deficits has been the focus of considerable attention in development macroeconomics (Agenor \& Montiel, 2008). We will examine below some of the theoretical and empirical issues that arise in the African context. The twin deficits assumption, also called the twofold deficit supposition or twin deficits irregularity, is a hypothesis from macroeconomics that contends that there is a robust association among a national economy's present description balance and its government financial plan balance. The double deficits theory traces back at least to the International Monetary Fund economist Polak's (1957) when he analyses the effects of specified monetary changes on income or on the balance of expenditures. The perseverance of large twin deficits in developed and developing countries for an extended period is due to increasing in public debt (domestic and foreign).

In fact and in the economic history, the self-styled double deficits assumption arose throughout the "Reagan fiscal experiment" in the 1980s, obvious time of robust appreciation of the dollar with atypical modification scramble in present balance deficits. The accessible literature related on double deficits hypothesis is largely paying attention on the interrelationships and/or the commoving relation in a bivariate construction linking internal balances and external deficits (or present description balances). In Europe, Germany and Sweden faced comparable troubles emerged in the early part of the 1990s where the increase in the country's government financial plan deficit was accompanied by authentic appreciation of their national currencies which unfavorably influence the present financial records situation (Ibrahim \& Kumah, 1996). This is not an exemption for African countries as most have also experienced difficulties with their existing account balances in near the beginning of 1980s.

According to the Ricardian standpoint (Ricardo, 1888), deficits financed by either debt or taxes are economically equivalent. In fact, for a known spending channel, replacement of debt for taxation has no consequence on total demand or in interest rates. Deficits could be financed through debt financing, taxes and printing money. Except 
taxes which are a leakage, both printing of money and debt financing are injections into the economy and could be inflationary if they are not properly and effectively managed. An internal deficit can be financed either by drawing down resources or incurring new liabilities of national and/or external. While use of resources is constrained by the stock and attractiveness of the assets, government, then, normally resort to internal borrowing (form the central bank, banking system, or private sector) and/or external borrowing (two-side or multilateral). Then again, any government borrowing entails a cost, in spite of its nature. External borrowing often appears more attractive for the government, because of less significant crowding out effects on private asset, and reduced risks of inflationary pressure. But, an increasing external debt tends to deteriorate the financial system. Additionally, when foreign debt is contracted on commercial terms, a higher external interest rate leads to an increase in debt service expenditures that may lead to a debt crisis.

With regards to the soundness of the Feldstein-Horioka theorem, households either face precise investment controls and/or basically require a favorite for external capital, both of which are uncertain in a world of extremely mobile investment. Balance due is created by the act of borrowing. Debt is considered as the resource or money use in an organization which is not contributed by its owner and does not in any other way belong to them. It is an accountability represented by a financial mechanism or other formal equivalent. In modern law, debt has no precise fixed meaning and may be regarded essentially as that which one person legally owes to another or an obligation that is enforceable by legal action to make payment of money. When government borrows, the money owing is a public debt. Public debts are either internal or external, incurred by the public sector through borrowing in the domestic and international markets so as to finance national investment.

Debts are categorized into two: productive debt and flat heaviness debt. When a loan is obtained to enable the state or nation to purchase some sort of assets, the debt is said to be productive for example, money borrowed for acquiring factories, electricity, and refineries. However, debt undertaken to finance wars and expenses on current expenditures are dead heaviness debts. When a country obtains a credit in a foreign country, it means that the country can import from abroad goods and services to the value of the loan without at the same time having to export anything for substitute. When capital and interest have to be repaid, the same country will have to get the burden of exporting goods and service without receiving any imports in exchange. Internal loans do not have the type of burden exchange of goods and services. These two categories of debt, however, require that the borrowers' future savings must cover the interest and main payment (debt servicing).

The objective of this article is to empirically analyze the causality association linking internal deficit and external deficit in some 15 African countries over the period 1960 and 2012. Four different questions can be addressed: Is internal deficit causes external deficit? Is there bidirectional causality between the two deficits? Are the double deficits not causally linked? And is external deficit causes internal deficit? This causal relationship has become an interesting research area for academics, policy makers and advisors in the past decades. The studies about this phenomenon are principally centered based on two most important economic theories: the Keynesian approach associated with the Mundell-Fleming framework and the Ricardian equivalence hypothesis. Data from Word Development Indicators (WDI) database, Penn World Table, and Historical Public Debt Database 2012 of International Monetary Fund are used. Descriptive statistics and econometric methods are utilized to analyze the causal relations between internal and external deficits. The content of the rest of the article is as followed: Section 2 analyzes the theoretical construction of the twin deficits hypothesis and reviews the empirical literature. Section 3 presents the methodology. The empirical results are presented and discussed in section 4 and section 5 concludes.

\section{Twin Deficits: Theoretical Framework and Empirical Literature}

From the eminent Keynesian macroeconomic framework resulting from the national revenue identity we get the following equations:

$$
Y=C+I+G+(X-M)
$$

and

$$
S+(T-G)=I+(X-M)
$$

Where, $Y$ is the national revenue. $C$ is the private consumption. $I$ is the private investment. $G$ is the government expenditures on goods and services. $X$ is the amount of exports of goods and services. $M$ is the amount of imports of goods and services. $(X-M)$ is the net exports or the trade balance or the external deficit. $S$ is the national savings or the private sector savings. $T$ is the government tax revenues.

After substitution, equation (2) becomes:

$$
(X-M)=(S-I)+(T-G)
$$


The equation (3) shows that the net exports are simply equal to the private saving-investment gap plus the budget balance. Equation (3) can be rewritten as follows:

$$
E D=I D+S I
$$

Where, $E D$ is the external deficit or exports balance. $I D$ is the internal deficit and $S I$ is the gap between private savings and private investments. The equation (4) shows the quasi-simultaneity of the external (trade) deficit and the internal (budget) deficit. The external deficit is the sum of two gaps: the internal deficit and the saving and investment balance. When assuming a constant saving - investment balance, a growing in internal deficit will directly amplify the external deficit.

From Nikiforos, Carvalho and Schoder (2013), we can now integrate the discussion of the trajectory of the governmental or public debt and internal deficit with some basic accounting identities that link the accumulation of debt with the deficit, the growth and interest rate and inflation. By defining each time $t$, the public debt is equal to the debt of the previous period plus the public deficit of the current period. Formally we can write the dynamic equation as follows:

$$
P D_{t}=P D_{t-1}+I D_{t}
$$

Where, $P D$ stands for public debt and $I D$ for the public or internal deficit. The subscript denotes the period each variable refers to. Stated differently, equation (5) can be rewritten as follows:

$$
\triangle P D_{t}=P D_{t}-P D_{t-1}=I D_{t}
$$

Where, $\Delta$ is the difference operator. In the traditional neo-classical model, public debt varies as a function of momentary increases in government expenditures (Barro, 1979).

Previously literature based on the twin deficits has mostly centered the debates on problems found on two main theoretical models. In spite of this, these are not the only potential results between the internal and external deficits. Actually, four probable causation linkages can be investigated linking the internal deficit and the external deficit: (1) internal deficit causes external balance, (2) there is bidirectional causality among the two variables, (3) the two gaps are not causally linked and (4) external deficits cause internal deficits. The first relationship is the traditional Keynesian intention (Keynes, 1936) often linked with the Mundell-Fleming representation (Mundell, 1963; Fleming, 1962). It argues that there exists a positive association between the double deficits. The causality is from the internal balance to the external deficit. In the context of this model, a rising in internal deficit causes an increase in national interest rate above the foreign rate, with capital inflows and appreciation of the national currency as effects. These effects, in turn, result in an increase in external (present account) balance.

A related literature shows that studies such as Hutchison and Pigott (1984), Zietz and Pemberton (1990), Bachman (1992), Vamvoukas (1999), Piersanti (2000), and Leachman and Francis (2002) without a doubt establish that internal deficit provokes an increase in foreign accounts deficits. In spite of this, analysis from Baharumshah and Lau (2007) indicate a uni-directional causal model from internal deficit to external deficit in Thailand. For illustration, the budget deficit does positively affect the current account deficit. Acaravci and Ozturk (2008) and Hakro (2009) have confirmed a comparable result for Turkey, and Pakistan, correspondingly.

Bidirectional causality exists between external and internal deficits. Despite the fact that internal deficits possibly will cause external deficits, the existence of significant view may source causality linking the two variables to run in mutual directions. In this situation, it is not adequate to reduce the internal balance in order to reduce external deficits. It is essential as well to harmonize budget-cut policies with a coherent box focusing on policies for export promotion, productivity improvement and exchange rate, among others. The empirical literature related to the bidirectional (or the double way) causality between internal deficit and external balance analyses the existence of significant feedback which cause causality between the two variables to run in both directions (Darrat, 1988; Normandin, 1999; Hatemi \& Shukur, 2002; Kouassi, Mbodja, \& Kymn, 2004; Lau \& Baharumshah, 2004). Lau and Baharumshah (2006) who analyze nine Asian countries in the panel setting, Jayaraman and Choong (2007) for statistics in Fiji while Arize and Malindretos (2008) for the majority of the African countries established that both internal deficit and external deficit depends on each other.

In difference, proponents of the Ricardian equivalence assumption put forward the absence of any association linking the external deficit and the internal balance. The Ricardian equivalence proposition states that deficits and taxations are equivalent in their effect on consumption (Barro, 1974). This analysis points out that, while a tax cut (hence a deficit) has the consequence of reducing public revenues and public savings and enlarging the internal balance. It increases private saving by an amount equal to the expected increase in the tax burden in future years. That is, savings will respond positively to the changes in budget deficits, leaving the trade deficit 
unaltered. Similarly, if government runs a deficit by borrowing, the economic agents expect that government will move up upcoming taxations to finance the budget deficit and so they increase their savings to meet the future tariff burden. In sum, alterations in the composition of public financing (for example, debt versus taxations) have no impact on real interest rate, total demand, private spending, the exchange rate or present account balance. In other words, the nonappearance of any Granger causality association among the double deficits would corroborate Ricardian equivalence hypothesis. The empirical analysis of Enders and Lee (1990), Evans and Hasan (1994), and Kaufmann, Scharler and Winckler (2002) assume that there is no relationship between the two deficits and hence is supportive of Ricardian equivalence hypothesis. The internal and external deficits are not really twins (Feldstein, 1992). However, Blanchard (1985) has abandoned the Ricardian argument by viewing that utility maximizing tax-payers would behave differently under a finite horizon as opposed to an infinite horizon as assumed by Ricardo. Blanchard (1985) suggests a positive correlation between sustained budget deficits and a country's external debt.

After all, the opposite causation from external to budget deficits can happen if excessive trade deficits push an financial system into a depression and consequently conduct to a financial or solvency crisis in which a large introduction of public funds may be required to re-establish the struggling financial sector or to minimize the gravity of a recession (Kim \& Donggeum, 2006). The large inflow of investment or debt accumulations affects the budgetary stance of a country and finally conducts to internal deficit. Investigations from Islam (1998), Anoruo and Ramchander (1998), Khalid and Guan (1999), Kim and Kim (2006) support the unidirectional of the link from external to internal deficits. Marinheiro's (2008) analysis has abandoned the double deficits hypothesis in maintaining of the transpose causality from external to internal deficits using the data from Egypt. According to them, this will appear if the government of a country utilizes their budget (fiscal) stances to affect the external balance. This representation of external adjustment might be especially relevant for developing countries (Khalid \& Guan, 1999).

Other authors such as Edwards (2001) and, Obstefeld and Rogoff (2004) have dealed with the double deficits debate from the point of view of macroeconomic stability of the economy. They have underlined that the negative implications of a mixture of adverse factors (for example double deficits, elevated interest rates and swap rate depreciation) would amplify the weakness of an economy and that the fiscal instruments are central for sensible macroeconomic policy for transition and developing economies. Consequently, the double deficits should be avoided.

In the Table 1 below, a summary of some relevant empirical analysis related on the Ricardian equivalence, the twin deficits (internal deficit-ID, external deficit-ED) hypotheses, the related developing countries and the causality results in time of series of studies is presented.

Table 1. A meta-analysis studies on Ricardian equivalence and/or twin deficits hypotheses without developed countries

\begin{tabular}{|c|c|c|c|}
\hline Author(s) and years & Developing countries concerned & Time period & Causality in time series studies \\
\hline Akbostanci and Tunç (2002) & Turkey & $1987-2001$ & Not valid \\
\hline $\begin{array}{l}\text { Anoruo and Ramchander } \\
\text { (1998) }\end{array}$ & $\begin{array}{c}\text { India, Indonesia, Korea, Malaysia, } \\
\text { Philippines }\end{array}$ & $1957-1993$ & $\mathrm{ED} \rightarrow \mathrm{ID}$ \\
\hline Baharumshah and Lau (2009) & $\begin{array}{c}\text { Indonesia, Japan, Malaysia, Singapore, } \\
\text { South Korea, Philippines, Thailand }\end{array}$ & $1980-2006$ & $\mathrm{ID} \rightarrow \mathrm{ED}$ \\
\hline Egwaikhide (1999) & Nigeria & $1973-1993$ & $\mathrm{ID} \rightarrow \mathrm{ED}$ \\
\hline Hakro (2009) & Pakistan & $1948-2005$ & $\mathrm{ID} \rightarrow \mathrm{ED}$ \\
\hline $\begin{array}{l}\text { Hashemzadeh and Wilson } \\
\qquad(2006)\end{array}$ & $\begin{array}{c}\text { Egypt, Iran, Jordan, Kuwait, Morocco, } \\
\text { Oman, Syria, Turkey, Yemen }\end{array}$ & $1982-2003$ & $\mathrm{ID} \leftrightarrow \mathrm{ED}$ \\
\hline Islam (1998) & Brazil & $1973-1991$ & $\mathrm{ID} \leftrightarrow \mathrm{ED}$ \\
\hline Marashdeh and Saleh (2006) & Lebanon & $1970-2004$ & $\mathrm{ED} \rightarrow \mathrm{ID}$ \\
\hline Mukhtar et al. (2007) & Pakistan & $1975-2005$ & $\mathrm{ID} \leftrightarrow \mathrm{ED}$ \\
\hline Nikiforos et al. (2013) & Greece & $1980-1995$ & $\mathrm{ID} \rightarrow \mathrm{ED}$ \\
\hline Onafowora and Owoye (2006) & Nigeria & $1970-2001$ & $\mathrm{ED} \rightarrow \mathrm{ID}$ \\
\hline
\end{tabular}




\begin{tabular}{cccc}
\hline Parikh and Rao (2006) & India & $1970-2000$ & ID $\rightarrow$ ED \\
Pattichis (2004) & Lebanon & $1982-1997$ & ID $\rightarrow$ ED \\
Ratha (2010) & India & $1998-2009$ & ID $\rightarrow$ ED \\
Saleh et al. $(2005)$ & Sri Lanka & $1970-2003$ & ID $\rightarrow$ ED \\
Vamvoukas (1999) & Greece & $1948-1994$ & ID $\rightarrow$ ED \\
\hline
\end{tabular}

Sources: Authors' elaborations.

From the above table, we notice that, the causality outcomes are varied, depending on the developing economy under consideration, the point in time and the period used.

\section{Methodology: Model, Variables, Data Sources and Descriptive Statistics}

\subsection{Model Specification}

To analyze the dynamics associations and to give good reason for the fundamental link among among the external deficit and the internal balance, we use the subsequent function:

$$
E D_{i t}=f\left(I D_{i t}\right) \text {, ceteris paribus }
$$

The function (7) can be presented in an econometric model as follows:

$$
E D_{i t}=\alpha_{0}+\alpha_{1} I D_{i t}+\alpha_{3} X_{i t}+\mu_{i t}
$$

Where, $E D_{i t}$ is the external deficit, $I D_{i t}$ is the internal deficit captured here with $\triangle P D_{i t}$ the variation of public debts, $\alpha_{0}$ is the constant term, $\alpha_{1}$ is the model coefficient, $\alpha_{3}$ is the coefficient of the control variables, $X_{i t}$ is the control variables, $\mu_{\mathrm{t}}$ is the random error term, $i$ is the country index $(i=1, \ldots, 15)$, and $t$ is time $(t=1960, \ldots$, 2012).

\subsection{Variable Selections}

As measure of internal deficit $(I D)$, we use the variation of public debt in percent of gross domestic productGDP (equation 6). While external deficit $(E D)$ is provide by external balance on goods and services (\% of GDP). Moreover, in order to separate the effect of the variation in the internal deficit on the variation of the external deficit, we use exchange rate $(E R)$ and consumer price index $(C P I)$ as control variables.

Internal deficit is the gap between incomes and expenditures for a government over a given period of time. It is often referred to as a public deficit or fiscal deficit. In many cases, countries have administrative subdivisions that also run significant fiscal deficits. The sum of state, local, and federal deficits constitute the internal deficit of these countries. On very rare occasions the concept is applied to the deficit run by private enterprises as well as by public sectors. In such case, the term is considered as the total debt of a country that is held by its own citizens. External balance on goods and services (formerly resource balance) is equal to exports of goods and services minus imports of goods and services (previously nonfactor services). External deficit is considered as a current account deficit. It is a negative net flow of liquid assets to the citizens of a particular country. The external balance includes the trade gap, the net foreign factor revenue and the net foreign aid received. Usually the most important cause of an external deficit is a trade deficit.

The rate at which one currency may be converted into another is called exchange rate. The exchange rate is used when simply converting one currency to another (such as for the purposes of travel to another country), or for engaging in speculation or trading in the foreign exchange market. There are a wide variety of factors which influence the exchange rate, such as interest rate, inflation, and the state of politics and the economy in each country. This term is also called rate of exchange or foreign exchange rate or currency exchange rate. Exchange rate measures of the value of a currency against a weighted average of several foreign currencies.

The consumer price index is a measure of changes in the purchasing-power of a currency and the rate of inflation. The consumer price index expresses the current prices of a basket of goods and services in terms of the prices during the same time in a previous year, to show effect of inflation on purchasing power. It is one of the best known lagging indicators. The consumer price index reflects changes in the cost to the average consumer of acquiring a basket of goods and services that may be fixed or changed at specified intervals. For the government expenditures, we used final consumption expenditure (formerly total consumption) which is the general government final consumption expenditure (general government consumption).

\subsection{Data Sources}

The data utilized in this paper cover the period 1960 to 2012 for 15 African countries: Angola, Cameroon, Central Africa Republic, Chad, Congo, Côte d'Ivoire, Democratic Republic of Congo, Egypt, Gambia, Ghana, 
Morocco, Nigeria, South Africa Republic, Tunisia, and Zambia. External balance on goods and services and Consumer price index are extracted from WDI database. Exchange Rate comes from Penn World Table, version 8.0. Public debt (\% of GDP) is provided by Historical Public Debt Database 2012 of International Monetary Fund.

\subsection{Descriptive Statistics}

Table 2 shows the summary statistics of the selected dependent, independent variables, and the control variables. The variables of the present study are linked to each other and the values of mean and median are in between the range of minimum and maximum values.

Table 2. Summary of descriptive statistics

\begin{tabular}{ccccc}
\hline & External Deficit & Exchange Rate & Consumer Price Index & Internal Deficit \\
\hline Mean & -0.228918 & 287.5495 & 61.95556 & -0.714114 \\
Median & -1.900766 & 9.550745 & 51.77515 & -0.098474 \\
Maximum & 52.47367 & 5046.109 & 2378.378 & 120.9910 \\
Minimum & -100.9709 & $1.67 \mathrm{E}-12$ & $2.35 \mathrm{E}-13$ & -161.4878 \\
Std. Dev. & 12.43114 & 669.5967 & 123.1100 & 19.10183 \\
Skewness & -0.221476 & 5.161885 & 14.51994 & -1.385621 \\
Kurtosis & 11.81240 & 32.35690 & 256.8663 & 20.29255 \\
Jarque-Bera & 1712.800 & 21304.97 & 1436411. & 6747.662 \\
Probability & 0.000000 & 0.000000 & 0.000000 & 0.000000 \\
\hline Observations & 528 & 528 & 528 & 528 \\
\hline
\end{tabular}

Source: Authors' calculations.

The Jarque-Bera test, in statistics, is a goodness-of-fit test of whether sample data have the skewness and kurtosis matching a normal distribution. The result of the statistic analysis and precisely the Jarque Bera test reveals that, for all series of data used in this paper the assumption of the normality of the error term of the distribution is abandoned.

\section{Empirical Results}

\subsection{Results of Panel Unit Test}

We start the presentation of the empirical results by exploring the temporal properties of the series. Table 3 presents the empirical results of the panel unit root test on the selected variables.

Table 3. Panel unit root test on variables

\begin{tabular}{ccccc}
\hline \multicolumn{4}{c}{ External DeficitExchange RateConsumer Price IndexInternal Deficit } \\
\hline Null: Unit root (assumes common unit root process) \\
\hline \multirow{2}{*}{ Levin, Lin and Chu t* } & $-6.99378^{* * *}$ & $\begin{array}{c}3.79217 \\
\left(-11.5774^{* * *}\right)\end{array}$ & $\begin{array}{c}7.84677 \\
(-1.00397)\end{array}$ & $-10.3439^{* * *}$ \\
& \multicolumn{4}{c}{ Null: Unit root (assumes individual unit root process) } \\
\hline \multirow{2}{*}{ Pesaran and Shin W-stat } & $-6.44337^{* * *}$ & 4.79363 & 12.5165 & $-12.0752^{* * *}$ \\
& & $\left(-12.5272^{* * *}\right)$ & $\left(-2.42101^{* * *}\right)$ & \\
ADF - Fisher Chi-square & $99.6689^{* * *}$ & 10.0358 & 0.68664 & $196.018^{* * * *}$ \\
& $\left(212.363^{* * *}\right)$ & $\left(88.5459^{* * *}\right)$ & \\
PP - Fisher Chi-square & $94.8534^{* * *}$ & $(7.91049$ & 0.31894 & $326.679^{* * *}$ \\
& & $\left(303.413^{* * *}\right)$ & $\left(107.607^{* * *}\right)$ \\
\hline
\end{tabular}

Note. Number in parentheses indicates the unit root test on variables in first differences. Probabilities for Fisher tests are computed using an asymptotic distribution. All other tests assume asymptotic normality. ***, ** and * respectively indicates significance at $1 \%, 5 \%$ and $10 \%$ level.

Source: Authors' calculations.

The Table 3 displays the panel unit root tests of external deficit, internal deficit, exchange rate and consumer 
price index series in level and in first differences. Firstly, the null hypothesis assumes common unit root process. After performing Augmented Dickey-Fuller (ADF) test we can see that external deficit and internal deficit are stationary in level $\mathrm{I}(0)$ and, exchange rate is stationary in difference I(1). Secondly, the null hypothesis assumes individual unit root process. Three tests also reveal that external deficit and internal deficit are stationary in level $\mathrm{I}(0)$ and our control variables, exchange rate and consumer price index are stationary in difference I(1).

\subsection{Linear Panel Causality Results}

Two types of panel regression methods are considered in this investigation: the pooled ordinary least square (OLS) model and the fixed effects (FE) model. The pooled OLS model assumes no variation of the coefficients and intercept terms while the FE model allows for variation within each country intercept (Hsiao, 2003; Craigwell \& Moore, 2008). The statistic tests, based on the two panel regression methods, are given from lags 1 to 3 and F-test is used to test restrictions on the coefficients at the chosen lag lengths which were determined by the Schwartz Bayesian Criterion (SBC), given the relative small sample utilized here.

The homogeneous causality hypothesis (HC) test results seen in Table 4 reveal non-causal relationship between external deficit and internal deficit. To make sure that the representation in Table 4 is well precise, we also run specification including exchange rate and consumer price index as control variables. These results suggest a robuts causal relationship from external deficit to internal deficit, and only one "lag" (OLS - no control) gives a significant causal relationship from internal deficit to external deficit. Nevertheless, about the models without controls variables, we find a strong causal relationship from external deficit to internal deficit, and a similar link from internal deficit to external deficit. Then, using the homogenous and instantaneous non-causality hypothesis (HINC) tests, the regression coefficients across countries are statistically different from zero and the null hypothesis is rejected (Table 4) for certain models.

Table 4. Homogenous and instantaneous non-causality tests (no controls and controls)

\begin{tabular}{|c|c|c|c|c|c|c|c|}
\hline & \multirow[b]{2}{*}{ Lags } & \multicolumn{2}{|c|}{ HINC (No control) } & \multicolumn{2}{|c|}{ HINC (with control) } & \multicolumn{2}{|c|}{$\mathrm{HC}$} \\
\hline & & OLS & FE & OLS & FE & OLS & $\mathrm{FE}$ \\
\hline \multirow{3}{*}{$E D \rightarrow I D$} & 1 & $13.41806^{* * *}$ & $12.93701 * * *$ & $57.21085^{* * *}$ & $54.46345^{* * *}$ & 1.38814 & - \\
\hline & 2 & $13.69234 * * *$ & $12.88241 * * *$ & $74.59394 * * *$ & $71.54537 * * *$ & 1.26778 & - \\
\hline & 3 & $14.02813 * * *$ & $12.72758 * * *$ & $76.56901 * * *$ & $72.80340 * * *$ & 0.58333 & - \\
\hline \multirow{3}{*}{$I D \rightarrow E D$} & 1 & $12.55463 * * *$ & $12.52379 * * *$ & $10.78071 *$ & 9.758554 & 0.54101 & - \\
\hline & 2 & $11.80330 * * *$ & $12.22474 * * *$ & 10.37381 & 9.128460 & 0.34034 & - \\
\hline & 3 & $15.29021 * * *$ & $14.16667 * * *$ & 15.87916 & 14.16630 & 0.99523 & - \\
\hline
\end{tabular}

Note. $* * * * *$ and $*$ respectively indicates significance at $1 \%, 5 \%$ and $10 \%$ level.

Source: Authors' calculations.

A supplementary finding concerns the heterogeneous non-causality hypothesis (HENC) test, which is also used to determine if the $\theta_{i k}$ coefficients are different across countries. Then Table 5 shows that five countries, Côte d'Ivoire, Gambia, Morocco, Democratic Republic of Congo and Tunisia, external deficit Granger caused internal deficit, two countries, Nigeria and Egypt, postulate causality from internal deficit to external deficit, and while one country, South Africa, reveal a bidirectional causal link between external deficit and internal deficit. For the other countries in our sample such as Angola, Cameroon, Congo, Ghana, Central Africa Republic, Chad and Zambia the macroeconomic association between internal and external deficit is established. But the macroeconomic relationship is not significant to be used for a robust conclusion.

Table 5. Heterogeneous Granger causality test

\begin{tabular}{ccc}
\hline Country & $E D \rightarrow I D$ & $I D \rightarrow E D$ \\
\hline Angola & 0.02954 & 0.23290 \\
Cameroon & 0.11636 & 0.32758 \\
Congo & 1.41985 & 0.01296 \\
Cote d'Ivoire & $6.23517^{* *}$ & 0.70908 \\
Egypt & 2.33350 & $4.70058^{* *}$ \\
Gambia & $6.51213^{* *}$ & 0.45263 \\
\hline
\end{tabular}




\begin{tabular}{ccc}
\hline Ghana & 0.22483 & 1.57857 \\
Morocco & $5.13655^{* *}$ & 0.13571 \\
Nigeria & 0.00063 & $5.76072 * *$ \\
Central Africa Republic & 0.0000 & 0.21733 \\
Demo. Rep. of Congo & $7.92307 * * *$ & 1.61025 \\
South Africa Republic & $3.80319 *$ & $5.53818 * *$ \\
Chad & 2.16867 & 0.02959 \\
Tunisia & $9.90735 * * *$ & 0.01620 \\
Zambia & 0.80089 & 0.57923 \\
\hline
\end{tabular}

Note. $* * *, * *$ and $*$ respectively indicates significance at $1 \%, 5 \%$ and $10 \%$ level.

Source: Authors' calculations.

\subsection{Non-Linear Panel Causality Results}

Using the non-linear panel causality, the empirical results obtained in the Table 6 suggest a significant non-linear causality solely for one causal variable when the external deficit is the dependent variable.

Table 6. Non-linear causality result: External deficit is the dependent variable

\begin{tabular}{cccc}
\hline Causal Variables & Lags & Coefficient & t-statistic \\
\hline ID & 1 & -0.095458 & $-2.220139^{* *}$ \\
ID2 & 2 & 0.000293 & 0.505890 \\
ID3 & 3 & $-2.36 \mathrm{E}-06$ & -0.834211 \\
\hline$\delta$ ID & 1 & 0.019182 & 0.488026 \\
$\delta I D 2$ & 1 & 0.000345 & 0.944520 \\
$\delta$ ID3 & 1 & 0.000000 & 0.710538 \\
\hline
\end{tabular}

Note. ${ }^{* * *}, * *$ and $*$ respectively indicates significance at $1 \%, 5 \%$ and $10 \%$ level. $\delta$ is the difference operator.

Source: Authors' calculations.

Table 7 shows the inexistence of the non-linear panel causality from internal deficit to external deficit.

Table 7. Non-linear causality result: Internal deficit is the dependent variable

\begin{tabular}{llll}
\hline Causal Variables & Lags & Coefficient & t-statistic \\
\hline ED & 1 & -0.074440 & -1.094510 \\
EDI2 & 2 & -0.004741 & -1.375433 \\
ED3 & 3 & $1.13 \mathrm{E}-05$ & 0.617356 \\
\hline$\delta E D$ & 1 & -0.060756 & -0.450115 \\
$\delta E D 2$ & 1 & 0.002095 & 0.419849 \\
$\delta E D 3$ & 1 & 0.0000 & 0.865626 \\
\hline
\end{tabular}

Note. ${ }^{* * *}, * *$ and * respectively indicates significance at $1 \%, 5 \%$ and $10 \%$ level. $\delta$ is the difference operator.

Source: Authors' calculations.

When using the non-linear panel causality with internal deficit considered as the dependent variable, the empirical results obtained in the Table 7 indicate the absence of a significant non-linear causality.

\section{Conclusions and Recommendations}

In this paper we have investigated the causality association between internal deficit and external deficit in 15 African countries during the period 1960-2012. Using causality analysis we have empirically tested the four main causation linkages: (1) internal deficit causes external deficit, (2) there is bidirectional causality between the two variables, (3) the two deficits are not causally related and (4) external deficits cause internal deficits. The estimates econometrically support that: external deficits cause internal deficits; internal deficit causes external deficit; and bidirectional causality between internal and external deficits. Our empirical results show that five countries, Côte d'Ivoire, Gambia, Morocco, Democratic Republic of Congo and Tunisia, external deficit Granger 
caused internal deficit, two countries, Nigeria and Egypt, postulate causality from internal deficit to external deficit, and while one country, South Africa, reveal a bidirectional causal link between external deficit and internal deficit.

Therefore, appropriate economic policy measures should be used to reduce internal deficits which would play an important role in reducing the external deficits and vice-versa. Important factors such as: improving the terms of trade, coordination of monetary and fiscal policies, sustaining the effort to enhance private saving, and consolidation of the fiscal taxes should be encouraged in order to increase public saving. Others monetary policies focused on the efficiency, as well as the exchange rate, will harmonize the budget cut policy. Finally, the control of national budgetary policies should be re-build.

\section{References}

Acaravci, A., \& Ozturk, I. (2008). Twin Deficits Phenomenon: Empirical Evidence from the ARDL Bound Test Approach for Turkey. Bulletin of Statistics and Economics, 2, 57-64.

Agenor, P. R., \& Montiel, P. J. (2008). Development Macroeconomics (3rd ed.). Princeton University Press.

Akbostanci, E., \& Tunç, G. İ. (2002). Turkish Twin Deficits: An Error Correction Model of Trade Balance. Economic Research Center Working Papers, 1(6).

Anoruo, E., \& Ramchander, S. (1998). Current Account and Fiscal Deficits: Evidence from Five Developing Economies of Asia. Journal of Asian Economics, 9, 487-501. http://dx.doi.org/10.1016/S1049-0078(99)80099-2

Arize, A. C., \& Malindretos, J. (2008). Dynamic Linkages and Granger Causality between Trade and Budget Deficits: Evidence from Africa. African Journal of Accounting, Economics, Finance and Banking Research, 2, 1-19.

Bachman, D. D. (1992). Why is the US current account deficit so large? Evidence from Vector Auto Regressions. Southern Economic Journal, 59, 232-240. http://dx.doi.org/10.2307/1060527

Baharumshah, A. Z., \& Lau, E. (2007). Dynamics of Fiscal and Current Account Deficits in Thailand: An Empirical Investigation. Journal of Economic Studies, 34, 454-475. http://dx.doi.org/10.1108/01443580710830943

Baharumshah, A. Z., \& Lau, E. (2009). Structural Breaks and the Twin Deficits Hypothesis: Evidence from East Asian Countries. Economics Bulletin, 29(4), 2517-2524.

Barro, R. J. (1974). Are Government Bonds Net Wealth? Journal of Political Economy, 82, 1095-117. http://dx.doi.org/10.1086/260266

Barro, R. J. (1979). On the Determination of Public Debt. Journal of Political Economy, 87, 940-971. http://dx.doi.org/10.1086/260807

Blanchard, O. J. (1985). Debt, Deficits and Finite Horizons. Journal of Political Economy, 93, 233-247. http://dx.doi.org/10.1086/261297

Craigwell, R., \& Moore, W. (2008). Foreign Direct Investment in SIDS: Evidence from Panel Causality Tests. Tourism Analysis, 13, 427-432.

Darrat, A. F. (1988). Have Large Budget Deficits Caused Rising Trade Deficits? Southern Economic Journal, 54, 879-886. http://dx.doi.org/10.2307/1059523

Drakos, K. (2001). Testing the Ricardian Equivalence Theorem: Time Series Evidence from Greece. Journal of Economic Development, 26, 1.

Edwards, S. (2001). Does Current Account Matter? National Bureau of Economic Research (NBER), Working Paper, 8275.

Egwaikhide, F. O. (1999). Effects of Budget Deficit on Trade Balance in Nigeria: A Simulation Exercise. African Development Review, 11(2), 265-289. http://dx.doi.org/10.1111/1467-8268.00011

Enders, W., \& Lee, B. S. (1990). Current Account and Budget Deficits: Twins or Distant Cousins? The Review of Economics and Statistics, 72, 373-381. http://dx.doi.org/10.2307/2109344

Evans, P., \& Hasan, I. (1994). Are consumers Ricardian? Evidence for Canada. Quarterly Review of Economics and Finance, 34, 25-40. http://dx.doi.org/10.1016/1062-9769(94)90051-5

Feldstein, M. (1992). The Budget and Trade Deficits aren't Really Twins. NBR Working Paper, 3966. 
http://dx.doi.org/10.3386/w3966

Feldstein, M., \& Horioka, C. (1980). National saving and international capital flows. Economic Journal, 90, 314-29. http://dx.doi.org/10.2307/2231790

Fleming, J. M. (1962). Domestic Financial Policies Under Fixed and Under Floating Exchange Rates. IMF Staff Papers, 9, 369-380. http://dx.doi.org/10.2307/3866091

Hakro, A. N. (2009). Twin Deficits Causality Link-Evidence from Pakistan. International Research Journal of Finance and Economics, 24, 54-70.

Hashemzadeh, N., \& Wilson, L. (2006). The Dynamics of Current Account and Budget Deficits in Selected Countries if the Middle East and North Africa. International Research Journal of Finance and Economics, $5,111-129$.

Hatemi, A., \& Shukur, G. (2002). Multivariate-based causality tests of twin deficits in the US. Journal of Applied Statistics, 29, 817-824. http://dx.doi.org/10.1080/02664760220136159

Hsiao, C. (2003). Analysis of Panel Data (2nd ed.). Cambridge: University Press. http://dx.doi.org/10.1017/CBO9780511754203

Hutchison, M. M., \& Pigott, C. (1984). Budget Deficits, Exchange Rates and Current Account: Theory and U.S. Evidence. Federal Reserve Bank of San Francisco Economic Review, 4, 5-25.

Ibrahim, S. B., \& Kumah, F. Y. (1996). Comovements in Budget Deficits, Money, Interest Rate, Exchange Rate and the Current Account Balance: Some Empirical Evidence. Applied Economics, 28, 117-130. http://dx.doi.org/10.1080/00036849600000014

Islam, M. F. (1998). Brazil's Twin Deficits: An Empirical Examination. Atlantic Economic Journal, 26, 121-128. http://dx.doi.org/10.1007/BF02299354

Jayaraman, T. K., \& Choong, C. K. (2007). Do Fiscal Deficits cause Current Account Deficits in the Pacific Island Countries? A Case Study of Fiji. University of South Pacific Working Paper, 8.

Kaufmann, S., Scharler, J., \& Winckler, G. (2002). The Austrian current account deficit: Driven by twin deficits or by intertemporal expenditure allocation? Empirical Economics, 27, 529-542. http://dx.doi.org/10.1007/s001810100094

Keynes, J. M. (1936). The General Theory of Interest, Employment and Money. Macmillan: London.

Khalid, A. M., \& Guan, T. W. (1999). Causality Tests of Budget and Current Account Deficits: Cross-Country Comparisons. Empirical Economics, 24, 389-402. http://dx.doi.org/10.1007/s001810050062

Kim, C. H., \& Kim, D. (2006). Does Korea have twin deficits? Applied Economics Letters, 13, 675-680. http://dx.doi.org/10.1080/13504850500404910

Kouassi, E., Mbodja, M. M., \& Kymn, K. O. (2004). Causality Tests of the Relationship Between the Twin Deficits. Empirical Economics, 29, 503-525. http://dx.doi.org/10.1007/s00181-003-0181-5

Lau, E., \& Baharumshah, A. Z. (2004). On the Twin Deficits Hypothesis: Is Malaysia Different? Pertanika Journal of Social Sciences and Humanities, 12, 87-100.

Lau, E., \& Baharumshah, A. Z. (2006). Twin Deficits Hypothesis in SEACEN Countries: A Panel Data Analysis. Applied Econometrics and International Development, 6(2), 209-222.

Lau, E., \& Tang, C. T. (2009). Twin deficits in Cambodia: Are there Reasons for Concern? An Empirical Study. Monash University, Discussion Paper, 11(9).

Leachman, L. L., \& Francis, B. (2002). Twin deficits: Apparition or reality? Applied Economics, 34, 1121-1132. http://dx.doi.org/10.1080/00036840110069976

Marashdeh, H., \& Saleh, A. S. (2006). Revisiting Budget and Trade Deficits in Lebanon: A Critique. University of Wollongong, Working Papers, 06-07. http://dx.doi.org/10.1016/j.jpolmod.2007.12.001

Marinheiro, C. F. (2008). Ricardian Equivalance, Twin Deficits and the Feldstein-Horioka Puzzle in Egypt. Journal of Policy Modeling, 30, 1041-1056.

Mukhtar, T., Zakaria, M., \& Ahmed, M. M. (2007). An Empirical Investigation for the Twin Deficit Hypothesis in Pakistan. Journal of Economic Cooperation, 28(4), 63-80.

Mundell, R. A. (1963). Capital Mobility and Stabilization Policy under Fixed and Flexible Exchange Rates. Canadian Journal of Economics and Political Science, 29, 475-485. http://dx.doi.org/10.2307/139336 
Nikiforos, M., Carvalho, L., \& Schoder, C. (2013). Foreign and Public Deficits in Greece: In Search of Causality. Levy Economics Institute, Working Paper, 771. http://dx.doi.org/10.2139/ssrn.2306572

Normandin, M. (1999). Budget Deficit Persistence and the Twin Deficits Hypothesis. Journal of International Economics, 49, 171-193. http://dx.doi.org/10.1016/S0022-1996(98)00058-0

Obstefeld, M., \& Rogoff, K. (2004). The Unsustainable U.S. Current Account Position Revisited. National Bureau of Economic Research, Working Paper, 10869.

Onafowora, O. A., \& Owoye, O. (2006). An Empirical Investigation of Budget and Trade Deficits: The Case of Nigeria. The Journal of Developing Areas, 39(2), 153-174. http://dx.doi.org/10.1353/jda.2006.0009

Parikh, A., \& Rao, B. (2006). Do Fiscal Deficits Influence Current Accounts? A Case Study of India. Review of Development Economics, 10(3), 492-505. http://dx.doi.org/10.1111/j.1467-9361.2006.00370.x

Pattichis, C. (2004). Budget and Trade Deficits in Lebanon. Applied Economics Letters, 11(2), 105-108. http://dx.doi.org/10.1080/1350485042000200204

Piersanti, G. (2000). Current Account Dynamics and Expected Future Budget Deficits: Some International Evidence. Journal of International Money and Finance, 19, 171-255. http://dx.doi.org/10.1016/S0261-5606(00)00004-8

Polak, J. J. (1957). Monetary Analysis of Income Formation and Payments Problems. International Monetary Fund, Staff Papers, 6, 1-50. http://dx.doi.org/10.2307/3866128

Ricardo, D. (1888). Essay on the Funding System. In The Works of David Ricardo. In J. R. McCulloch (Ed.), With a Notice of the Life and Writings of the Author. John Murray: London.

Saleh, A. S., Nair, M., \& Agalewatte, T. (2005). The Twin Deficits Problem in Sri Lanka: An Econometric Analysis. South Asia Economic Journal, 6(2), 221-239. http://dx.doi.org/10.1177/139156140500600204

Vamvoukas, G. A. (1999). The twin deficits phenomenon: Evidence from Greece. Applied Economics, 31, 1093-1100. http://dx.doi.org/10.1080/000368499323571

Zietz, J., \& Pemberton, D. K. (1990). The US budget and trade deficits: A simultaneous equation model. Southern Economic Journal, 57, 23-34. http://dx.doi.org/10.2307/1060475

\section{Copyrights}

Copyright for this article is retained by the author(s), with first publication rights granted to the journal.

This is an open-access article distributed under the terms and conditions of the Creative Commons Attribution license (http://creativecommons.org/licenses/by/3.0/). 